Оригинални научни рад

343.123.5:351.74(497.11)

doi:10.5937/zrpfns50-12772

Snežana M. Soković, Ph.D., Full Professor

University of Kragujevac

Faculty of Law Kragujevac

ssokovic@jura.kg.ac.rs

Dragana S. Čvorović, Ph.D., Assistant Professor

Academy of Criminalistic and Police Studies

Belgrade

dragana.cvorovic@kpa.edu.rs

Veljko M. Turanjanin, Ph.D., Assistant Professor

University of Kragujevac

Faculty of Law Kragujevac

vturanjanin@jura.kg.ac.rs

\title{
COOPERATION BETWEEN THE PUBLIC PROSECUTOR AND THE POLICE IN SERBIA*
}

\begin{abstract}
Contemporary trends in criminal procedure legislation are deliberately looking for efficiency as well as the instruments of implementation of international standards both in its quantitative and qualitative aspects. Doctrinal considerations find their footing in the decades-long reform of criminal procedural legislation of the Serbia, whereas the question that has always represented one of the most significant characteristics of criminal procedural legislation in general is the correlation between the public prosecutor and the police and its contribution to the efficiency of criminal proceedings. Serbia adopted new Criminal Procedure Code in 2011, which entered into the force during the 2013. According to the abovementioned, the authors pay special attention to the following issues: first, the notion of the police and the police functions; secondly, the correlation of the public prosecutor and the police as a factor in the efficiency of criminal proceedings; thirdly, empirical research and proposals de lege ferenda.
\end{abstract}

Keywords: police, public prosecutor, an international standard, the reform of criminal legislation.

* Research is the result of work on the project "Implementation of the New Serbian Code of Criminal Procedure". The project is funded by the European Union, 2015. 


\section{INTRODUCTION: THE NOTION OF THE POLICE AND POLICE FUNCTIONS}

The distinctive theoretical bases, when it comes to the modern meaning of the term police that are viewed from a historical aspect, which was exposed to a significant number of changes, imply a constant qualitative development and improvement of the system of the internal organization and pretensions of modern states for increasing the number of field-specific and specialized forms of the government operations, and all with the aim of better treatment in all aspects of the social action, which would result in prosperity. When it comes to the concept of the police which existed in ancient times, the word police was usually brought into connection with the Roman notion politia that originated in the Greek term polis (city state) and politieia (lifestyle and organization of a community or a general thing of all citizens of the polis), and through the extensive correlation of the aforementioned concepts ${ }^{1}$, we can hardly connect them directly with the position of the concept of the modern state police. ${ }^{2}$ We can conclude that by specifying the concept of the police in such a manner, we set the relationship of equality with the state. In other words, the beginning of the development stage of the country is identified with the police. Historically, different meanings are attributed to the concept of the police, most of them being brought in connection with the concept of the state administration, government services or public order. However, the aspect of the modern concept of the police with which we meet today, starts only from the end of the VIII century and the early IX century, when the notion of the police in their functional sense was linked to the ministry that deals with the maintenance of public order and peace, security and order, the preservation of freedom, property and personal security. When it comes to reviewing aspects of the concept of the police to combat crime, it came only at the end of the IX century when, at the same time, the final determination by the police activity from the other departments of internal administration was manifested. The European trend of the meaning of the notion of police does not deviate to a large extent in the countries of Europe and the contemporary trends of its development. Accordingly, in the English language the word police has the meanings of the organized civilian force to maintain order, prevention and detection of crime and the enforcement of laws; members of these forces; regulation and control in the community, especially in regard to the maintenance of public order, safety, health, morals, etc.; government departments responsible for carrying out police duties, especially those related to the maintenance of order; any group of people in charge or employees to safeguard

\footnotetext{
${ }^{1}$ By the notion of Politieia, among other things, Aristotle considered ideal state organization, which was a mixture of democratic and aristocratic principles. See: Aristotle, Politics, Culture, Belgrade 1960, 215.

${ }^{2}$ Ljubomir Tadić, The Science of Politics, Rad, Belgrade 1988, 17. (Serbian)
} 
order and enforcement of laws. ${ }^{3}$ In the French language, the police stands for the branch of the state authority that ensure the maintenance of public order, personal safety or property; the building of the working premises of the police; all agents and the administration ${ }^{4}$. The German term Polizei and Italian polizia have the similar previously stated meanings of the word. In the Russian language, the main meaning of the police in organizational terms is a "special state administration body with the task of preserving security and order of the authorities". ${ }^{5}$

However, the inconsistency of doctrinal understanding of the meaning of the concept of the police has led to a large number of definitions, and the first modern dates from 1885. After 1915, the American author Fozdik stated his understanding of the meaning of the concept of police as follows: "What we consider to be police nowadays are primarily forces guaranteed by the Constitution which are to protect the individual within their legal rights." Also, Rob Mawby points out that the notion of police involves every agency that may differ with regard to the legitimacy, structure and function. In accordance with the definitions set out front, there is a legitimate question, considering the complexity of this concept, which is whether it is possible to define the concept of police in a relatively comprehensive way, and thus avoiding reducing police only to its key elements and characteristics. Given all this, by defining the police as a "complex system of professional type, which was organized in order to maintain public peace and order in the society and which is for this purpose provided with statutory powers and resources, including the means of coercion"', Milosavljevic rightly points out that the police should be seen as a dynamic system that interacts with its environment, emphasizing that its professional characteristics are done to restrict this concept to the bodies and institutions performing police duties in the form of public services, which excluded various forms of subsidiary and private police from the definition of the police. Bearing in mind all the foregoing, the police can be defined as a separate, specific state authority complex type that is organized to ensure the maintenance of law and order in a society, and that is for this purpose provided with statutory powers and resources include the means of coercion. In accordance with such a concept of the police, its main features are as follow:

The police in its organization and functioning are not only special, but also a specific state authority;

\footnotetext{
${ }^{3}$ The Oxford Dictionary: A New English Dictionary on Historical Principles, Clarendon Press, Oxford 1933, 1069-1070.

${ }^{4}$ New Larousse Encyclopedia, JRJ, Belgrade 1999.

${ }^{5}$ See more: Stanko Bejatović, Milimir Govedarica, Police in the Criminal Proceedings, Banja Luka 2014, 258. (Serbian)

${ }^{6}$ S. Bejatović, M. Govedarica, 258.

${ }^{7}$ Bogoljub Milosavljevic, Police Science, Academy of Criminalistic and Police Studies, Belgrade 1997, 11-14. (Serbian)
} 
Regardless of the country where the police are formed, it stands as such a state body which is organized for the purpose of maintaining public peace and order in a society, and thus ensuring the rule of law in the society;

In order to achieve its primary task of organization, the police realize multiple functions (powers);

All of its police powers are implemented in accordance with the law and the appropriate regulation;

To achieve the function of its existence, the police have statutory powers supplied with the necessary means;

One of the means for exercising its functions is also the means of coercion. ${ }^{8}$

Finally, in relation to this, we would like to point out that, although modern tendencies have distinctive approaches to determine the concept of the police in relation to the term that existed in history, this does not mean that in those original communities people did not deal with the terms in question, but over time attitudes, organization, regulation, social relations, the need in it have been modified, so "the process of creating the first country led to a gradual escalation of those forms of regulation of social relations and sanction violations that recognizes the original communities in the institutions of state power". ${ }^{9}$ When it comes to the concept of a police function as well as with the concept of police, the attitude of the majority of authors in terms of pluralism and talk about the stated problem as a concept and type of policing functions is justified, rather than the concept of police functions, which finds its foundation in more facts. On the first place, the number of police functions, i.e. the quantitative aspect, implies the function. Also, police functions and activities taken by the police in the exercise thereof vary significantly from country to country. Furthermore, police functions are dynamic in nature, i.e. variable in their content, not only when we take into account the different countries (and even different cities within a single country), but especially if we bear in mind the different periods in which they have existed.10 Until the $60^{\text {th }}$, there was the dominant view that the most important and most common police activity was related to crime prevention and detection of criminal offenders. However, such opinion was soon abandoned, based on the first basic research on the basis of which the police clearly recognized that much more time is spent in activities that have a social utility character, help people in their small everyday problems than in activities related to the fight against crime. ${ }^{11}$ Surveys

\footnotetext{
${ }^{8}$ Dragana Čvorović, Deprivation and Restriction of Liberty by the Police, Doctoral Dissertation, Faculty of Law, University of Belgrade 2016, 249. (Serbian)

${ }^{9}$ Ibid., 250.

${ }^{10}$ Ibid., 251.

${ }^{11}$ Elaine, Cumming, Laura Edel, Ian Cumming, The Policman as Philosopher, Guide and Friend, according to: Samuel Walker, The Police in America: An Introduction, McGraw-Hill, Inc., New York 1992, 22.
} 
conducted in connection with this show that the overall volume of police works in combating crimes account for only $20 \%-30 \% .^{12}$ In line with this, we can conclude that the function of the police cannot be reduced only to the prevention and repression of crime, but that it has a very important social-utility segment. Bearing in mind the results of research, the mythical notion of the police was redefined as an agency for the fight against crime. ${ }^{13}$ From the aspect of criminal functions, in other words, prevention and repression of crime, we mainly refer to the international standards of the right to life, prohibition of inhuman, degrading treatment or punishment, and the right to liberty and security of person, the right to a fair trial, which is in accordance with their character and hierarchical primary location on the social scale, may be restricted only in cases prescribed by the law, and to respect and achievement of their set as crucial in contemporary society, and the situation deviations from the absolutist approach must be interpreted narrowly. Among the many functions of the police, two are of particular importance when it comes to the preliminary investigation and criminal proceedings and as such they make the memorial of police of all countries. The first function is to combat crime, which unites two aspects - preventive and repressive. The second function is the maintenance of public order and social services segment. However, what connects these two functions is that in neither of the segments the police stand as the only bearer of functions as well as the activities undertaken with the aim of achieving them, despite the fact that the police have a key role. For example, the effectiveness of combating crime, depends not only on effective police work in this field, but also on the efficiency of engagement of many other social actors whose role in the fight against crime is considered to be very important.

\section{CORRELATION OF THE PUBLIC PROSECUTOR AND THE POLICE AS A FACTOR OF THE EFFICIENCY OF THE CRIMINAL PROCEEDINGS}

The effectiveness as an international standard, especially in the suppression of crime, depends not only on effective police work ${ }^{14}$ in this field, but also on the efficiency of engagement of many other social actors whose role in the fight against

${ }^{12}$ S. Walker, 83; Steven M. Cox, Police: Practices, Perspectives, Problems, Allyn and Bacon, Boston 1996, 22.

${ }^{13}$ It should be noted that the entertainment industry - the media, movies, are significantly responsible for this image of the police, but also to the police itself maintains this image that it usually comes before the public with information relating to the performance in the fight against crime (although this fight is much easily quantified and statistically shown, but various forms of social service work of the police).

${ }^{14}$ Bogoljub Milosavljević, Human Rights and Police, Center for the antiwar Action, Belgrade 2004. (Serbian) 
crime is considered very important. In accordance with the reformed criminal procedure legislation of Serbia, ${ }^{15}$ the police together with the public prosecutor ${ }^{16}$ stand as the key subject in the preliminary proceedings, ${ }^{17}$ both in taking actions of operational-tactical character, and the evidence gathering, which, if taken in accordance with the Code, may be used in further proceedings. The legal basis for the actions taken by the police is provided by the Art. 286 of the Criminal Procedure Code in the following manner: "If there are grounds for suspicion that a criminal offense is prosecutable ex officio has been committed, the police is required to implement necessary measures to locate the perpetrator of the criminal offence, for the perpetrator or accomplice not to go into hiding or abscond, to detect and secure traces of the criminal offence and objects which may serve as evidence, as well as to collect all information which could be of benefit for the successful conduct of criminal proceedings". From the standpoint of criminal procedure, ${ }^{18}$ the role of the police in preliminary investigation proceedings in the field of implementation of international standards is immeasurable, but it is a necessary response to the question whether the mutual relation of the subjects of the preliminary investigation ${ }^{19}$ and at which level, contributes to the implementation of

${ }^{15}$ Milan Škulić, "Misconceptions and Numerous Legal and Technical Errors of the New Criminal Procedure Code - What to do Next and How to Reform the Reform of Serbian Criminal Procedure", Reform of Criminal Law (ed. Goran Ilić), Belgrade 2014, 23- 66; Vojislav Đurđić, "Conceptual Downward in the New Criminal Procedure Code of Serbia", Reform of Criminal Law (ed. Goran Ilić), Belgrade 2014, 66-87; Vojislav Đurđić, "Starting and Control of Public Prosecution Investigation", Prosecutorial investigation, OSCE Mission to Serbia, Belgrade 2014, 139-153; Milan Škulić, Criminal Procedure Law, Faculty of Law, University of Belgrade, Belgrade 2014; Vojislav Đurđić, "The Prospect of a New Model of Criminal Procedure Serbia", Journal of Criminalistic and Law 2/2015, 71- 97; Tatjana Bugarski, "Direct Accusation”, Prosecutorial Investigation (eds. Ivan Jovanović, Ana Petrović-Jovanović), OEBS Mission to Serbia, Belgrade 2014, 221- 233; (Serbian); Dragana Čvorović, Veljko Turanjanin, "Reformed Criminal Procedure Legislation and Serbian Police Legitimacy in Europe (Doctrine, Statistics and Consistency)", Archibald Reiss Days vol. 1 (ed. Đorđe Đorđević), Academy of Criminalistic and Police Studies, Belgrade 2016, 483-494.

${ }^{16}$ Goran Ilić, "Position of the Public Prosecutor according to the New Serbian Criminal Procedure Code", New Trends in Serbian Criminal Procedure Law and Regional Perspectives (eds. Ana Petrović, Ivan Jovanović), OSCE Mission to Serbia, Belgrade 2012, 70-77; Dragana Čvorović, „Public Prosecutor as a Powerful Figure of the Modern Criminal Procedure Legislation“, Crime and Society of Serbia: Challenges of the Social Disintegration, Social Regulation and Environmental Protection (eds. Marina Hugson, Zoran Stevanović), Institute of Criminological and Sociological Research, Belgrade 2015, 223 - 237. (Serbian)

${ }^{17}$ Goran Ilić, "Pre-investigation", Manual for the Implementation of the Code of Criminal Procedure (eds. Stanko Bejatović, Milan Škulić, Goran Ilić), Association of Public Prosecutors and Deputy Public Prosecutors of Serbia, Belgrade 2013, 211- 230. (Serbian)

${ }^{18}$ Stanko Bejatović, "The Effectiveness of the Criminal Proceedings as an International Legal Standard", Criminal Legislation of Serbia and the European Union Standards (ed. Stanko Bejatović), Serbian Association for Criminal Legal Theory and Practice, Belgrade 2010, 184-208. (Serbian)

${ }^{19}$ Dragana Čvorović, "Public Prosecutor and the Police as the Key Subjects of the Preliminary Investigation Phase and the Investigation Phase New Criminal Procedure", The Position and 
international standards. The answer to this question contains three special features: firstly, the concrete form of cooperation between these categories of operators depends on the type of subjects and actions whose undertaking under their jurisdiction, and the actions of which they are the holders. Secondly, the efficiency of the treatment of these subjects determines not only on the effectiveness of the actions in which those are taking part, but also the efficiency of the preliminary investigation as a whole. Thirdly, the principles of activity, professionalism, legality and mutual respect must be the principles of mutual relations and cooperation between these entities regardless of the occasion which actions these relations are established. ${ }^{20}$ Only full compliance of these principles by the subjects of the preliminary investigation is the basis of efficiency of the preliminary investigation and is understood in qualitative and quantitative ${ }^{21}$ terms. ${ }^{22}$ Because of all this, full attention must be given to establishment of these relations, and above all, by the public prosecutor as the head of the preliminary investigation. Accordingly, compliance with these principles of mutual relations between active entities in a preliminary investigation is not only the basis of the legality of actions taken, but also the guarantee of the efficiency of the undertaking and the basis of its contribution to the efficiency of the preliminary investigation as a whole, or criminal proceedings.

\section{EMPIRICAL RESEARCH AND PROPOSALS DE LEGE FERENDA}

The conducted research regarding the relationship between police and public prosecutors in the reformed criminal procedure legislation of Serbia, confirmed the initial hypothesis that this is one of the most important and the most pressing issues when it comes to criminal-legal matter (theory and practice) in general. In order to evaluate the adequacy of using the criminal procedure norms by the public prosecutor and the police we have conducted the empirical research. Its goal is the following: firstly, understanding the scope and ways of mutual cooperation between the public prosecutor and the police in pretrial investigation and investigation procedure and the impact of this cooperation on the efficiency of detecting and proving criminal acts and their perpetrators and implementation of international

Role of the Police in a Democratic State, Criminalistic and Police Academy, Belgrade 2013, 111- 139. (Serbian)

${ }^{20}$ D. Čvorović (2016), 197

${ }^{21}$ Slavoljub Carić, "The Right to Trial within a Reasonable Time in Criminal Matters: the Attitudes of the European Court of Human Rights", The Main Hearing and Trial within a Reasonable Time (eds. Stanko Bejatović, Ivan Jovanović), OSCE Mission to Serbia, Belgrade 2015, 34- 49. (Serbian)

${ }^{22}$ Vojislav Đurđić, "Criminal Procedure Law as a Normative Assumption of the Efficiency of Procedures in Criminal Matters", Criminal Legislation, Organization and Efficiency of the Judiciary in Criminal Matters (ed. Stanko Bejatović), Serbian Association for Criminal Legal Theory and Practice, Belgrade 2008, 9-39. (Serbian) 
standards and secondly, making proposals for removing negativity in the application of legal provisions by these two processing entities. The justification of the empirical research of these issues emerged as necessary for the reasons of the changed procedural position of these two subjects in the CCP from 2011. We conducted the survey between public prosecutors and member of the police. In this work, we analyzed attitudes of the public prosecutor's. In accordance with the conducted research, the basic characteristics of mutual cooperation between the public prosecutor and the police in preliminary investigation and pre-trial investigation in order to realize efficiency as an international standard are as follows.

The cooperation between prosecution and the police is not very satisfactory, which is particularly evident when it is viewed from the perspective of the police were $14,3 \%$ of respondents defined this cooperation as bad, $40,3 \%$ as satisfactory and only $36,4 \%$ as good and $9 \%$ as a very good. Bearing in mind the position of the police and the public prosecutor in the concept of the new CPC, especially the leadership role of the public prosecutor in the preliminary investigation procedure, it is necessary to make the cooperation more qualitative by the authorization of the police and the new concept of investigation.

\section{How would you assess your cooperation with the police?}

Percentage Total answered

Bad

Satisfactory

$14,3 \%$

11

Good

$40,3 \%$

31

Very good

$36,4 \%$

28

$9,0 \%$

7

Answered the question

Did not answer the question

It is a significant number of coordination meetings held between the prosecution and the police and the subject of their discussion in a small number of cases $(38,9 \%)$ was related to the topic in question. Those were very general meetings. However, we have to bear in mind the fact that it is hard to answer to the concrete issues before the implementation of the new CPC.

2. Prior to the entry into force of the CPC did you have any coordination meeting with the police on the topic of your future cooperation (changed) by the new CPC?

Yes

Percentage

Total answered

No

$67,5 \%$

52

$32,5 \%$

25

Answered the question 77

Did not answer the question 
3. Meetings were related to:

Generally to the subject of the cooperation

$\begin{array}{cc}\text { Percentage } & \text { Total answered } \\ 61,1 \% & 33 \\ 38,9 \% & 21\end{array}$

To the concrete topics

Answered the question

Did not answer the question

Structurally speaking, the quality of criminal charges submitted by the police to the public prosecutor is not at the required level. Only in 44, 9\% of cases, the public prosecutor may, on the basis of the submitted complaint and its annex immediately decides on the opening or closing the investigation. If the public prosecutor cannot assess from the criminal complaint if its assertions are probable, or if the data in the complaint do not provide sufficient grounds to decide whether to conduct an investigation, or if he finds out in some other way that a criminal offence has been committed, the public prosecutor may: 1) collect the necessary data himself; 2) request citizens [to provide information], under the prescribed conditions; 3) submit a request to public and other authorities and legal persons to provide necessary information (article 282).

4. Are the criminal charges sent to you by the police usually such that on their basis you can immediately decide whether to open an investigation or not?

$\begin{array}{lcc} & \text { Percentage } & \text { Total answered } \\ \text { Yes } & 44,9 \% & 35 \\ \text { No } & 55,1 \% & 43\end{array}$

Answered the question

78

Did not answer the question

Insufficient own actions taken by the police in a case of reasonable suspicion of committing a criminal offense are the problem (art. $286 \mathrm{CPC}$ ). According to the results of the conducted survey among holders of public prosecution office, the police "regularly and on its own initiative take this action" 23 only in $1,6 \%$ of cases (always) and 47,4\% (often).

5. Do the police regularly and on its own initiative take actions provided for in Article 286 of the CPC?

Always

Often

Rare

Never

$\begin{array}{cc}\text { Percentage } & \text { Total answered } \\ 1,3 \% & 1 \\ 47,4 \% & 37 \\ 34,6 \% & 27 \\ 16,7 \% & 13\end{array}$

Answered the question

Did not answer the question

${ }^{23}$ D. Čvorović (2016), 550. 
As we said, if there are grounds for suspicion that a criminal offence which is prosecutable ex officio has been committed, the police is required to implement necessary measures to locate the perpetrator of the criminal offence, for the perpetrator or accomplice not to go into hiding or abscond, to detect and secure traces of the criminal offence and objects which may serve as evidence, as well as to collect all information which could be of benefit for the successful conduct of criminal proceedings. For the purpose of fulfilling these duties referred, the police may: seek necessary information from citizens; perform necessary inspection of vehicles, passengers and luggage; restrict movement in a certain space for a necessary period of time and up to a maximum of eight hours; undertake necessary measures in connection with the establishment of the identity of persons and objects; post a wanted circular for a person and objects being searched for; in the presence of a responsible person inspect certain facilities and premises of public authorities, enterprises, shops and other legal persons, inspect their documentation and if needed seize it; undertake other necessary measures and actions. A transcript or an official note will be made of facts and circumstances established during the performance of certain actions, as well as objects found or seized, which may be of interest for the criminal proceedings. Acting on an order of the public prosecutor the police may for the purpose of fulfilling the duties obtain a record of telephone communications or the base stations used, or perform location of the place from where a communication is being conducted. The police immediately, or no later than 24 hours after performing them, notify the public prosecutor about the performance of the measures and actions. A person against whom any of the measures and actions has been applied is entitled to submit a complaint to the competent public prosecutor.

\section{Do the police inform you about the actions taken pursuant to article 286 ?}

Percentage Total answered

Within 24 hours

$77,3 \%$

58

After 24 hours

$18,7 \%$

14

Never

$4,0 \%$

3

Answered the question 75

Did not answer the question

One of the most important police activities is the undertaking activities on the crime scene. Usually, the police first find out the felony. ${ }^{24}$ However, the police have to notify the public prosecutor about that step. As we can see, in the $86,1 \%$ the police inform the prosecutor before undertaking activities on the crime scene, but in the $13,9 \%$ it take this step during the investigation on the crime scene. The

\section{7. (Serbian)}

${ }^{24}$ Milan Škulić, Tatjana Bugarski, Criminal Procedure Law, Faculty of Law, Novi Sad 2015, 
fact that is especially troubling if notifying after the activities on the crime scene, which is not justifiable. The prosecutor goes to the crime mostly when he evaluate that it is necessary $(96,2 \%)$.

7. When undertaking an investigation on the crime scene, the police notifies you: Percentage Total answered

Before undertaking an investigation on the crime scene

$\begin{array}{cc}86,1 \% & 68 \\ 13,9 \% & 11 \\ 5,0 \% & 4\end{array}$

Answered the question

Did not answer the question

8. When you are timely notified about the crime, do you go to a crime scene?

Percentage Total answered

Yes, always

$2,5 \% \quad 2$

Yes, when I evaluate that it is necessary $\quad 96,2 \% \quad 76$

Never

Answered the question

Did not answer the question

The prosecutor is the main actor in the criminal procedure and investigation. He is not obliged to discuss about the strategy with the police, but it could be useful. However, that is rare.

9. Upon receipt of the criminal report, do you meet with the police to discuss the strategy of the investigation?

Yes Percentage Total answered

No $33,3 \%$ 25

$66,7 \%$ 50

Answered the question 75

Did not answer the question

The public prosecutor leads the pre-investigation proceedings. For the purpose of exercising the authority, the public prosecutor undertakes necessary actions aimed at prosecuting the perpetrators of criminal offences. The public prosecutor may assign to the police the undertaking of certain actions aimed at detecting criminal offences and locating suspects. The police are required to execute the order of the public prosecutor and to inform him regularly about actions undertaken. Due to this obligation, the prosecutor has to provide adequate instructions to the police. 
10. What instructions do you usually give to the police?

General (take any necessary actions)

$\begin{array}{cc}\text { Percentage } & \text { Total answered } \\ 10,0 \% & 8 \\ 90,0 \% & 72\end{array}$

be taken)

Answered the question

Did not answer the question

If the prosecutor is not able to undertake the actions by himself, the public prosecutor will request the police to collect the necessary information and to undertake other measures and actions with the aim of uncovering the criminal offence and the perpetrator. According to the article $282 \mathrm{CPC}$, the police are obliged to act in accordance with the request of the public prosecutor and to notify him about the measures and actions it had undertaken not later than 30 days from the date of receiving the request. In the most cases, the police do not respect this deadline.

11. Do the police respect the 30-day deadline for the execution of your request?

$\begin{array}{cc}\text { Percentage } & \text { Total answered } \\ 36,4 \% & 28 \\ 63,6 \% & 49\end{array}$

Yes

No

$63,6 \%$

Answered the question

In the next three tables we examined situations where the police did not take ordered action, did take the action that is not ordered and took the banned action.

12. Have you ever encountered a situation where the police have not taken action that you have ordered?

Yes

$\begin{array}{cc}\text { Percentage } & \text { Total answered } \\ 76,1 \% & 54 \\ 23,9 \% & 17\end{array}$

Answered the question

Did not answer the question

13. Have you ever encountered a situation where the police took the action that you have not ordered?

Yes

Percentage Total answered

No

$62,7 \% \quad 42$

$37, .31 \%$

25

Answered the question 
14. Have you ever encountered a situation where the police took the action that you have banned?

Yes

$\begin{array}{cc}\text { Percentage } & \text { Total answered } \\ 5,2 \% & 4 \\ 94,8 \% & 73\end{array}$

Answered the question

Did not answer the question

In some cases, the public prosecutor can initiate a disciplinary proceeding against the member of the police. Where the police or other public authority does not comply with a request of the public prosecutor, the public prosecutor will immediately notify thereof the head of that authority, and may, if needed, also notify the competent minister, the Government or the competent working body of the National Assembly. If within 24 hours of the time when the notification was received the police or other public authority fails to comply with the request of the public prosecutor, the public prosecutor may request the institution of disciplinary proceedings against the person who he believes is responsible for not complying with his request (article $44 \mathrm{CPC}$ ).

15. Have you ever encountered a situation where a police officer receives the order from his superior that is contrary to yours?

$\begin{array}{lcc} & \text { Percentage } & \text { Total answered } \\ \text { Yes } & 41,8 \% & 33 \\ \text { No } & 58,2 \% & 46\end{array}$

Answered the question 79

Did not answer the question 2

16. Have you ever asked for initiation of disciplinary proceedings in accordance with Article 44 of the CPC?

Yes

Percentage Total answered

No

$4,0 \%$

3

$96,0 \%$ 73

Answered the question

Did not answer the question

17. If yes, do you know the outcome of your initiative?

$\begin{array}{lcc} & \text { Percentage } & \text { Total answered } \\ \text { Yes } & 8,3 \% & 2 \\ \text { No } & 91,7 \% & 22\end{array}$

Answered the question 
18. If you are familiar with the outcome, has disciplinary proceeding been initiated? Yes Percentage Total answered

No $22,2 \%$ 14

\section{Answered the question \\ Did not answer the question}

If the police conduct an evidentiary action during the pre-investigation proceedings, it will inform the public prosecutor thereof without delay. Evidence obtained by the police by conducting evidentiary actions may be used in the further course of the criminal proceedings if the evidentiary actions were conducted in accordance with the CPC (article $287 \mathrm{CPC}$ ).

\section{Did the police notify you without delay of evidentiary actions undertaken during the preliminary investigation, in accordance with the Article 287 of the CPC?

$\begin{array}{lcc} & \text { Percentage } & \text { Total answered } \\ \text { Yes } & 75,0 \% & 57 \\ \text { No } & 25,0 \% & 19\end{array}$

Answered the question

Did not answer the question

When the police collect information from a person for whom there exist grounds for suspicion that he is the perpetrator of a criminal offence, or undertake towards that person actions in the pre-investigation proceedings stipulated by his Code, they may summon him only in the capacity of a suspect. The suspect will be advised in the summons that he is entitled to obtain a defense counsel. If during collection of information the police find that the citizen summoned may be deemed a suspect, they are required to advise him immediately of his rights and of the right to obtain a defense counsel who will attend his questioning. The police will notify the competent public prosecutor without delay about these acting. The public prosecutor may conduct the suspect's questioning, attend the questioning or assign the questioning to the police. If the suspect agrees to make a statement, the authority conducting the questioning will act in accordance with the provisions of the CPC relating to the questioning of a defendant provided that the consent of the suspect to be questioned and his statement during the questioning are given in the presence of his defense counsel. The transcript of this questioning is not excluded from the files and may be used as evidence in criminal proceedings. If the public prosecutor is not present at the questioning of a suspect, the police will deliver to him without delay the transcript of the questioning (article 289 CPC). 
20. Have you ever entrusted the interrogation of the suspect to the police?

Yes, once or several times

Percentage Total answered

Yes, often

$40,3 \%$

31

Never

$37,7 \%$

$22,0 \%$

17

Answered the question

Did not answer the question

The prosecutor, according to the $\mathrm{CPC}$, can entrust the witness and expert interrogation to the police. But, it is not easy decision, and in the most cases, the prosecutor interrogates witnesses and expert himself.

21. Have you ever entrusted the interrogation of witnesses to the police?

$\begin{array}{cc}\text { Percentage } & \text { Total answered } \\ 11,5 \% & 9 \\ 9,0 \% & 7 \\ 79,5 \% & 62\end{array}$

Answered the question

Did not answer the question

22. Have you ever entrusted the interrogation of expert to the police?

Yes, once or several times

Percentage Total answered

Yes, often

$1,3 \%$

1

Never

$0,0 \%$

0

$98,7 \%$

77

Answered the question

Did not answer the question

An investigation is initiated by an order issued by the competent public prosecutor. An order to conduct an investigation is issued before or immediately after the first evidentiary action undertaken by the public prosecutor or the police in the pre-investigation proceedings, but not later than 30 days after the public prosecutor was notified about the first evidentiary action undertaken by the police. The order to conduct an investigation must specify the following: the personal data of the suspect, if his identity is known, the description of the act on which the legal elements of a criminal offence are based, the legal qualification of the criminal offence and the circumstances from which the grounds for suspicion are derived. 
23. Do you inform a police officer working on the specific case about the order on conducting the investigation?

Yes

Percentage Total answered

No

$18,4 \%$

14

$81,6 \%$

62

Answered the question

Did not answer the question

24. If yes, do the police still take actions on their own initiative?

Yes

Percentage Total answered

No

$14,3 \%$

30

Answered the question

Did not answer the question

From the last table we can see that $65,5 \%$ of the questioned police officers consider that the "existing legal framework does not adequately regulate the relationship between the prosecutor and the police". This is not a surprise, because the whole CPC in far from the ideal legal text. According to it, this field should be improved, because cooperation between the public prosecutor and police has to be perfect.

25. Does the existing legal frame adequately regulate relationship between the prosecutor and the police?

Yes

Percentage Total answered

No

$34,5 \%$

19

$65,5 \%$

36

Answered the question

Did not answer the question

According to the conducted research, there has been still insufficient level of comprehensive knowledge of the provisions of the new Criminal Procedure Code as for its effect has a practical non-implementation of some of its provisions in accordance with the intentions of the legislator, in addition to ignorance of legal provisions, adversarial and imprecision of the new CPC of Serbia also, one of the indicators of distinction in the practical application of the provisions of the CPC Serbia. Those statements can also be ordered as proposals in achieving the desired efficiency, through a better understanding of legal provisions by the police and public prosecutors, and adequate elaboration of normative legal explicit, given that the normative basis is one of the most important factors of efficiency, in line with trends and attitudes in modern doctrine of criminal law. Also, the 
valid theoretical point of view when it comes to the role of the police in the comparative criminal procedure imply much more active position of the police in the previous criminal proceedings, and bearing in mind the positive experiences of these countries in terms of efficiency of the police in this case, it is necessary to take into account their solutions, and thus create a normative basis for more efficient functioning of the state organs, especially in the correlation with the public prosecutor. 
Др Снежана М. Соковић, редовни йрофесор

Универзитетеи у Краг̄ујевиу

Правни факулиетеи у Крагуујевиу

ssokovic@jura.kg.ac.rs

Др Драг̄ана С. Чворовић, доиений

Криминалисииччко-йоличијска академија

Београд

dragana.cvorovic@kpa.edu.rs

Др Вељко М. Турањанин, доценит

Универзитетеи у Краг̄ујевиу

Правни факулиетей у Краг̄ујевиу

vturanjanin@jura.kg.ac.rs

\section{Сарадња јавног тужиоца и полиције у Републици Србији}

Сажсейак: Савремени тирендови у кривичнойрочесном законодавстиву

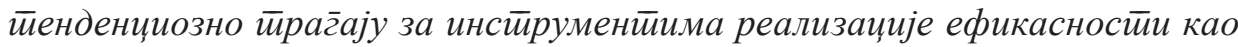

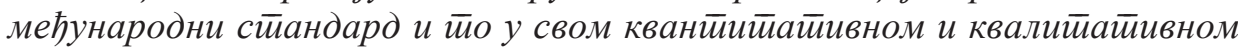

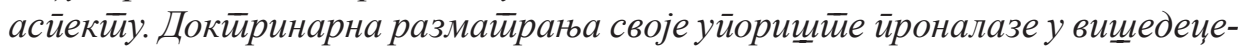
нијској реформи кривичнойроцесног̄ законодавстива Србије, а йитиање које је одувек иредсииављало једно од значајнијих обележја кривичнойроиесног̄

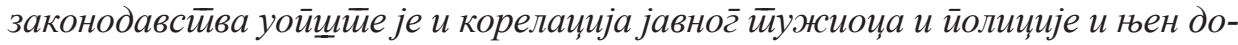

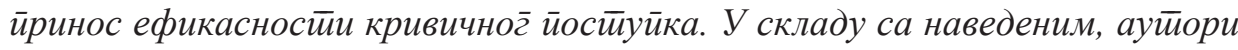
йосебну йажњу йосвећују следећим йийањима: ирво, иооам йолиције и йо-

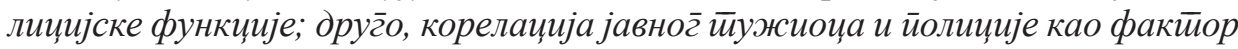

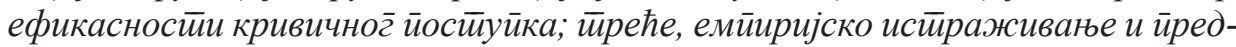
лози de lege ferenda.

Кључне речи: йоличија, јавни йужсилаи, међународни стиандард, реформа кривичнойрочесног̄ законодавсиива.

Датум пријема рада: 21.12.2016. 